\title{
Effects of different chilling procedures on honey bees (Apis mellifera) for anesthesia
}

\author{
Hidayet TUTUN ${ }^{1, a}$, Sedat SEVİN ${ }^{2, b, \bigotimes}$, Bekir ÇETINTAV ${ }^{3, c}$ \\ ${ }^{1}$ Burdur Mehmet Akif Ersoy University, Faculty of Veterinary Medicine, Department of Pharmacology and Toxicology, Burdur; \\ ${ }^{2}$ Ankara University, Faculty of Veterinary Medicine, Department of Pharmacology and Toxicology, Ankara; ${ }^{3}$ Burdur Mehmet Akif \\ Ersoy University, Faculty of Science, Department of Statistics, Burdur, Turkey.

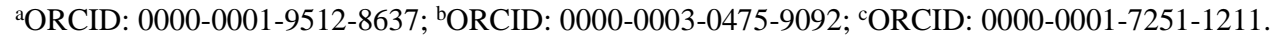

${ }^{凶}$ Corresponding author: sedatsevin59@ gmail.com Received date: 02.11.2019- Accepted date: 10.01 .2020

\begin{abstract}
Immobilization is required for the examination and manipulation of honey bees (Apis mellifera), and many techniques have been developed to render honey bees immobile until this date. Among them, two methods, which are carbon dioxide $\left(\mathrm{CO}_{2}\right)$ and low-temperature narcosis, have been commonly used to induce anesthesia on the bees. Although $\mathrm{CO}_{2}$-induced anesthesia changes the behavior and physiology of honey bees, the anesthesia induced by cold is considered commonly as non-damaging for the bees. There are a very limited number of studies on the effects of different chilling protocols in honey bees. Therefore, the purpose of this study was to investigate the effect of different chilling procedures on the survival rate and depth of anesthesia in honey bees. A total of 4 groups were formed, one of which was the control group. Three temperatures $\left(+4^{\circ} \mathrm{C},-20^{\circ} \mathrm{C}\right.$ and $\left.-80^{\circ} \mathrm{C}\right)$ were applied to three different experimental groups. Furthermore, four different exposure times were implemented on each experimental group ( $\mathrm{n}=20$ worker bees in each trial). The depth of anesthesia was assessed and scored based on the movements and anesthesia recovery time in honeybees. There was a statistically significant relationship between duration and survival/death rate in the applications at $+4{ }^{\circ} \mathrm{C},-20^{\circ} \mathrm{C}$ and $-80^{\circ} \mathrm{C}$ $(\mathrm{P}<0.001)$. The method that was applied for 5 minutes at $-20^{\circ} \mathrm{C}$ was the most ideal chilling method $(\mathrm{P}<0.03)$ and showed the lowest mortality in addition to the high depth of anesthesia. This study may assist in selecting the safest and deepest anesthesia method required in any study on honey bees.
\end{abstract}

Keywords: Anesthesia, chilling, honey bee.

\section{Anestezi için farklı soğutma prosedürlerinin bal arıları (Apis mellifera) üzerine etkileri}

Özet: Bal arılarının (Apis mellifera) incelenmesi ve manipülasyonu için hareketsiz kılınmasına ihtiyaç vardır. Bu zamana kadar bal arılarını hareketsiz kılmak için birçok teknik geliştirilmiştir. Bunlar arasında karbondioksit $\left(\mathrm{CO}_{2}\right)$ ve düşük sıcaklık ile anestezi en çok kullanılan teknikler olmuştur. $\mathrm{CO}_{2}$ kaynaklı anestezi bal arılarındaki davranışı ve fizyolojiyi değiştirse de, soğuk anestezi genel olarak arılar için zararsız kabul edilir. Bal arılarındaki farklı soğutma protokollerinin etkileri üzerine yapılan çalışmalar oldukça sınırlıdır. Bu çalışmanın amacı, farklı soğutma prosedürlerinin bal arılarındaki sağkalım ve anestezi derinliği üzerindeki etkisini araştırmaktır. Biri kontrol grubu olmak üzere toplam 4 grup oluşturuldu. Üç farklı sıcaklık $\left(+4^{\circ} \mathrm{C},-20^{\circ} \mathrm{C}\right.$ ve $\left.-80^{\circ} \mathrm{C}\right)$ üç farklı gruba uygulandı ve her deney grubuna dört farklı maruz kalma süresi uygulandı (her denemede $\mathrm{n}=20$ işçi arı). Anestezi derinliği, bal arılarındaki hareketlere ve anestezi iyileşme sürelerine dayanan bir skorlamaya göre değerlendirildi. $+4^{\circ} \mathrm{C},-20^{\circ} \mathrm{C}$ ve $-80^{\circ} \mathrm{C}$ 'deki uygulamalarda süre ve sağkalım/ölüm oranı arasında istatistiksel olarak anlamlı bir ilişki bulundu $(\mathrm{P}<0,001) .-20^{\circ} \mathrm{C}$ 'de 5 dakika süreyle uygulanan yöntem, en düşük ölüm ve yüksek derinlikte anestezi ile en ideal soğutma yöntemi $(\mathrm{P}<0,03)$ olarak bulundu. Bu çalışma, bal arıları üzerinde bireysel olarak yapılacak bilimsel çalışmalarda gerekli olan en güvenli ve en derin anestezi yönteminin seçimine olanak sağlayabilir.

Anahtar sözcükler: Anestezi, bal arısı, soğuk anestezi.

\section{Introduction}

Honey bees (Apis mellifera) have a crucial role in global biodiversity as pollinators. As the recognition for the importance of honey bees increases, the number of the studies on the breeding, diseases and treatment of honey bees, and on bee products (e.g. honey, pollen) has increased (3, 17, 20, 28). Researchers have developed several techniques to facilitate bee manipulation in those studies due to their capacity to be aggressive at any time $(7,19)$. Anesthesia of bees has been used as an approach 
to facilitate their examination and to minimize pain and distress during potentially painful procedures. Although there have been efforts to develop a possible technique since then in order to immobilize the bees without killing them, a safe technique has not been developed yet to meet all needs in bee anesthesia $(5,18)$.

The use of applicable techniques that have low mortality and toxicity is essential for the anesthesia of bees. Carbon dioxide $\left(\mathrm{CO}_{2}\right)$ has been commonly used in the anesthetization of honey bees $(5,8,21,22)$. However, it has been reported that $\mathrm{CO}_{2}$ affects their behavior and physiology, causes them to age faster, starts forage earlier and shortens their life span in honey bees $(4,9,13,14,18$, 27). Moreover, other substances including diethyl ether and nitrogen have been used for anesthesia (15). Their use has been limited due to toxic effects of these substances on honey bees, their cost, and lack of laboratory equipment for gas anesthesia. For this reason, chilling, which is another common technique, has been used for many years as an alternative to these substances for temporarily immobilizing honey bees and reducing the handling stress $(8,12,15)$.

Endothermic heat production and organized structure of the cluster allow the bees to survive in cold winter $(25,26)$. Hypothermia can be used to slow the metabolic rate of bees, and thus facilitate their handling $(2$, 16). A chilling method is considered to be non-invasive and non-damaging for neural structures, and its effect is reversible. Some invertebrates do not tolerate chilling very well, and may eventually die. Depth of anesthesia, recovery time and mortality can be changed by temperature, the length of time exposed to cold temperature, the method used and the species of honey bee in the anesthetization of honey bees applied by being exposed to cold (12). There is little information available on cold-anesthesia in honey bees. Therefore, it is necessary to determine the most ideal and safe chilling anesthesia method in honey bees. The purpose of this study was to investigate the effect of different procedures of chilling on the survival capacity and depth of anesthesia, and to find the optimal exposure time and temperature for cold-narcosis in honey bees.

\section{Material and Methods}

Honey bee collection and study design: Honey bee workers (A. mellifera) were collected from a colony in Ankara, Turkey. They were kept in an incubator (Panasonic MLR-352H-PE) for three days $\left(36^{\circ} \mathrm{C}, 50 \%\right.$ $\mathrm{RH}$ ) and fed with $50 \%$ sucrose solution supplied $\mathrm{ad}$ libitum with a gravity feeder before treatments. We have investigated the effects of different chilling protocols on the anesthesia depth and survival rate of honey bees by using a design with four main groups according to the applied temperature: (Control group) at $+25^{\circ} \mathrm{C},($ Group 1$)$ at $+4{ }^{\circ} \mathrm{C},\left(\right.$ Group 2) at $-20^{\circ} \mathrm{C}$, and (Group 3) at $-80^{\circ} \mathrm{C}$. A cage with 20 worker bees was used in each trial, resulting in 80 bees for control group. Each experimental group (Group 1, 2 and 3) was divided into 4 subgroups. Except for the control group, each trial in subgroups had a cage with 20 worker bees, resulting in 960 bees in total for the experimental groups (shown in Table 1). Each trial was performed four times.

Analysis of mortality and anesthesia depth in honey bees: Honey bees were caged (20 per cage) under the control group and 3 different experimental groups. A refrigerator (Arçelik, $4252 \mathrm{EY}$ ) and two freezers (Panasonic MPR-414F-PE; Panasonic MDF-U5386S) were used in chilling processes. The bees were cooled in their cages at temperatures that were selected by us (11). Different temperatures and exposure times applied in the groups are demonstrated in Table 1. After the application of different chilling protocols to bee groups, the cages were kept at room temperature in order to examine the depth of anesthesia and mortality. Bees from each treatment group were examined with regard to the depth of anesthesia by three veterinarians. The depth of anesthesia was assessed according to the scoring based on bee movements (walking, creep, and antenna movement, flapping, flying, immobility) and recovery time (shown in Table 2). In the score used to determine the depth of anesthesia, Levels 4 and 5 were recognized as operable for honey bee manipulation. After examination, they were housed in the same incubator and fed with the same sugar solution that was provided ad libitum. The surviving bees were counted for 2 hours after chilling treatments.

Table 1. Groups formed and different chilling protocols applied to the groups

\begin{tabular}{lcccc}
\hline & Control Group & Group 1 & Group 2 & Group 3 \\
\hline Temperatures & $+\mathbf{2 5}^{\circ} \mathbf{C}$ & $+\mathbf{4}^{\circ} \mathbf{C}$ & $\mathbf{- 2 0}^{\circ} \mathbf{C}$ & $\mathbf{- 8 0}^{\circ} \mathbf{C}$ \\
\hline Method 1 & - & 5 min. & 1 min. & $30 \mathrm{sec}$. \\
Method 2 & - & 10 min. & 3 min. & 1 min. \\
Method 3 & - & 20 min. & 5 min. & 3 min. \\
Method 4 & - & 30 min. & 10 min. & 5 min. \\
\hline
\end{tabular}

20 worker bees were used in each trial. 
Table 2. Scoring of depth and duration of anesthesia

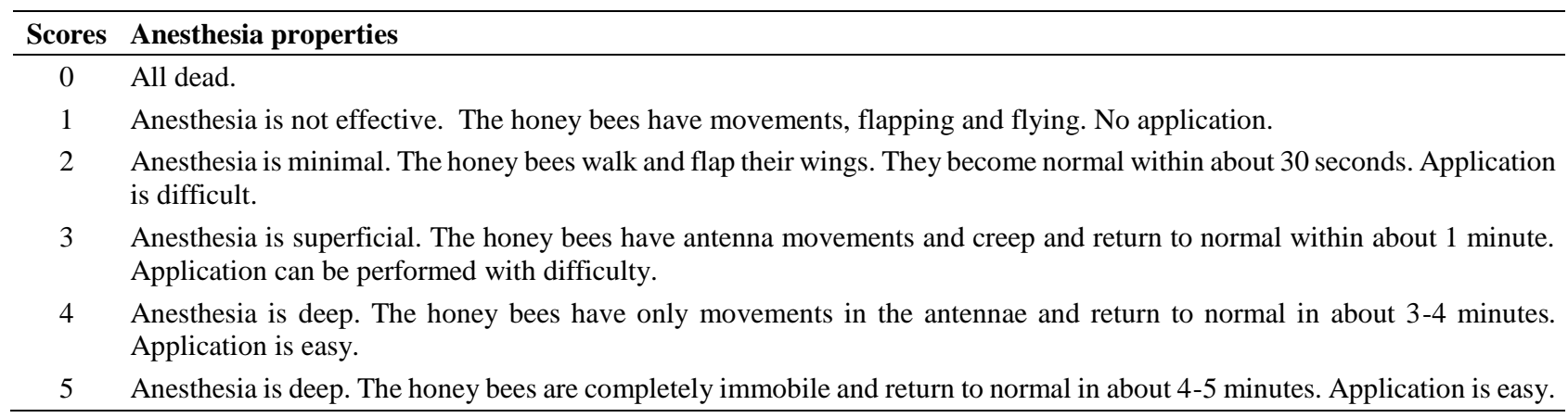

Table 3. Survival rates $(\%)$ of honey bees after different chilling methods.

\begin{tabular}{|c|c|c|c|c|c|c|c|c|c|}
\hline \multirow[t]{2}{*}{ Temperature } & \multirow[t]{2}{*}{ Duration } & \multicolumn{2}{|c|}{ Death } & \multicolumn{2}{|c|}{ Live } & \multicolumn{2}{|c|}{ Total } & \multirow{2}{*}{$\begin{array}{c}\text { Anesthetic } \\
\text { level }\end{array}$} & \multirow{2}{*}{$\mathbf{P}$} \\
\hline & & $\mathbf{n}$ & $\%$ & $\mathbf{n}$ & $\%$ & $\mathbf{n}$ & $\%$ & & \\
\hline \multirow{4}{*}{$\begin{array}{l}+4^{\circ} \mathrm{C} \\
\text { (Group 2) }\end{array}$} & $5 \mathrm{~min}$. & 0 & $0.00 \%$ & 80 & $100 \%$ & 80 & $100 \%$ & 2 & \multirow{4}{*}{$\begin{array}{l}\text { Pearson's } \\
\text { Chi-square }=25.68 \\
P<0.001\end{array}$} \\
\hline & $10 \mathrm{~min}$. & 0 & $0.00 \%$ & 80 & $100 \%$ & 80 & $100 \%$ & 3 & \\
\hline & $20 \mathrm{~min}$. & 6 & $7.5 \%$ & 74 & $92.5 \%$ & 80 & $100 \%$ & 4 & \\
\hline & $30 \mathrm{~min}$. & 13 & $16.25 \%$ & 67 & $83.75 \%$ & 80 & $100 \%$ & 5 & \\
\hline \multirow{4}{*}{$\begin{array}{l}-20^{\circ} \mathrm{C} \\
\text { (Group 3) }\end{array}$} & $1 \mathrm{~min}$. & 0 & $0 \%$ & 80 & $100 \%$ & 80 & $100 \%$ & 2 & \multirow{4}{*}{$\begin{array}{l}\text { Pearson's } \\
\text { Chi-square }=201.96 \\
P<0.001\end{array}$} \\
\hline & $3 \mathrm{~min}$. & 2 & $2.5 \%$ & 78 & $97.5 \%$ & 80 & $100 \%$ & 3 & \\
\hline & $5 \mathrm{~min}$. & 3 & $3.75 \%$ & 77 & $96.25 \%$ & 80 & $100 \%$ & 5 & \\
\hline & $10 \mathrm{~min}$. & 61 & $76.25 \%$ & 19 & $23.75 \%$ & 80 & $100 \%$ & 5 & \\
\hline \multirow{4}{*}{$\begin{array}{l}-80^{\circ} \mathrm{C} \\
\text { (Group 4) }\end{array}$} & $30 \mathrm{sec}$. & 9 & $11.25 \%$ & 71 & $88.75 \%$ & 80 & $100 \%$ & 4 & \multirow{4}{*}{$\begin{array}{l}\text { Pearson's } \\
\text { Chi-square }=248.99 \\
\mathrm{P}<0.001\end{array}$} \\
\hline & $1 \mathrm{~min}$. & 11 & $13.75 \%$ & 69 & $86.25 \%$ & 80 & $100 \%$ & 5 & \\
\hline & $3 \mathrm{~min}$. & 80 & $100 \%$ & 0 & $0 \%$ & 80 & $100 \%$ & 0 & \\
\hline & $5 \mathrm{~min}$. & 80 & $100 \%$ & 0 & $0 \%$ & 80 & $100 \%$ & 0 & \\
\hline
\end{tabular}

Values are expressed as percentage. For all chilling methods $\left(+4^{\circ} \mathrm{C},-20^{\circ} \mathrm{C}\right.$ and $\left.-80^{\circ} \mathrm{C}\right)$, a statistically significant relation was determined between the variables of duration and survival rate $(\mathrm{P}<0.05)$.

Statistical analysis: Normality assumption was preliminarily checked with Shapiro-Wilks test for each data set. Pearson's Chi-Squared test was preferred to test the relation between the variables of duration and survival rate. One of the non-parametric alternatives of the independent samples t-test, Mann-Whitney $U$ test was used to determine the difference between the applicable (Level 4 and Level 5) durations for three different application temperatures $\left(+4^{\circ} \mathrm{C},-20^{\circ} \mathrm{C}\right.$ and $\left.-80^{\circ} \mathrm{C}\right)$. Finally, One-way ANOVA was used for comparing Level 5 chilling protocols. Tukey's and Duncan's tests were applied as post-hoc tests for pairwise comparisons. All statistical analyses were performed with IBM-SPSS 22 package program.

\section{Results}

Chi-square test showed that there was a statistically significant relationship between duration and survival / death rate in applications at $+4^{\circ} \mathrm{C},-20^{\circ} \mathrm{C}$ and $-80^{\circ} \mathrm{C}(\mathrm{P}$ $<0.001$ ) (Table 3). According to Tukey's test results, the method that was applied for 5 minutes at $-20^{\circ} \mathrm{C}$ showed lower mortality rate than methods that lasted 30 minutes at $+4^{\circ} \mathrm{C}(\mathrm{P}=0.007)$, for 1 minute at $-80^{\circ} \mathrm{C}(\mathrm{P}=0.030)$ and for 10 minutes at $-20^{\circ} \mathrm{C}(\mathrm{P}<0.001)$. Although there was no statistically significant difference between the application that lasted 30 minutes at $+4^{\circ} \mathrm{C}$ and 1 minute at $-80^{\circ} \mathrm{C}(\mathrm{P}=$ 0.846), 30 minutes at $+4^{\circ} \mathrm{C}$ had lower mortality rate than 10 minutes at $-20^{\circ} \mathrm{C}(\mathrm{P}<0.001)$. The method applied for 1 minute at $-80^{\circ} \mathrm{C}$ had a lower mortality rate than 10 minutes at $-20^{\circ} \mathrm{C}(\mathrm{P}<0.001)$. Although the depth of anesthesia reached operable levels (Level 4 and 5) at $+4^{\circ} \mathrm{C}$ for 20 minutes and over, mortality rates increased with these methods in Group 1. Low mortality rate and Level 3 depth of anesthesia were observed in Method 3 application in Group 1. Aggression and stinging behavior were not observed despite the presence of movement in the bees, and the easy application was only possible for 1 minute since the bees were completely awakened from anesthesia after 1 minute at room temperature with Method 3 on Group 1. Anesthesia at Level 5 was observed at $-20^{\circ} \mathrm{C}$ for 5 and 10 minutes in Group 2. However, high mortality rate was observed in Method 4 application in this group. Furthermore, it was determined that Method 3 showed optimal anesthesia in this group, especially as it provided 
low mortality and immobility in the bees for up to 5 minutes. All honey bees were dead at $-80^{\circ} \mathrm{C}$ for 3 and 5 minutes. Although Methods 1 and 2 showed high level of anesthesia, there was also high mortality rate in this group (Table 3).

A comparison of methods with anesthetic Levels 4 and 5 (operable) is presented in Table 5. Although there was no statistically significant difference between the methods at Level $4\left(+4^{\circ} \mathrm{C} / 20 \mathrm{~min},-80^{\circ} \mathrm{C} / 30 \mathrm{sec}\right.$. $)(\mathrm{P}=$ $0.200)$, the difference between the chilling methods at Level 5 was statistically significant $(\mathrm{P}<0.001)$. According to Duncan-Homogeneous subsets test: 5 minutes at $-20^{\circ} \mathrm{C}$ was in subset $\mathbf{a}(\mathrm{P}=1.000)$ with the lowest mortality (the best result); 30 minutes at $+4^{\circ} \mathrm{C}$ and 1 minute at $-80^{\circ} \mathrm{C}$ were in the subset of $\mathbf{b}(\mathrm{P}=0.430)$ with moderate mortality (the second best result); and 10 minutes at $-20^{\circ} \mathrm{C}$ was in the subset of $\mathbf{c}(\mathrm{P}=1.000)$, which had the highest mortality rate (the worst result) among these 4 methods with Level 5. Five minutes at $-20^{\circ} \mathrm{C}$ provided the lowest death rate, and there was a statistically significant difference between 30 minutes at $+4^{\circ} \mathrm{C}, 1$ minute at $-80^{\circ} \mathrm{C}$ and 10 minutes at $-20^{\circ} \mathrm{C}(\mathrm{P}=0.007, \mathrm{P}=0.030$ and $\mathrm{P}<0.001$, respectively $)$ with regard to death rate. There was no statistically significant difference between methods at Level $4(\mathrm{P}=0.200)$. The results of this study showed that the method applied for 20 minutes at $+4^{\circ} \mathrm{C}$ may be used in any study for which anesthesia Level 4 will be sufficient.

Table 4 .The comparison of death rate in honey bees for operable (Level 4 and 5) chilling methods.

\begin{tabular}{|c|c|c|c|c|c|c|}
\hline Temperature & Duration & Death & Live & Death/Total & Average & Comparison* \\
\hline \multirow{8}{*}{$\begin{array}{c}+4^{\circ} \mathrm{C} \\
(\text { Group 2) }\end{array}$} & \multirow{4}{*}{20 min..$^{b}$} & 1 & 16 & 0.05 & \multirow{4}{*}{0.075} & \multirow{8}{*}{$\begin{array}{c}\text { Mann-Whitney } U=15,00 \\
P=0.057\end{array}$} \\
\hline & & 2 & 18 & 0.10 & & \\
\hline & & 1 & 17 & 0.10 & & \\
\hline & & 1 & 16 & 0.05 & & \\
\hline & \multirow{4}{*}{$30 \mathrm{~min}}$. & 4 & 16 & 0.20 & \multirow{4}{*}{0.1625} & \\
\hline & & 2 & 18 & 0.10 & & \\
\hline & & 3 & 17 & 0.15 & & \\
\hline & & 4 & 16 & 0.20 & & \\
\hline \multirow{8}{*}{$\begin{array}{c}-20^{\circ} \mathrm{C} \\
(\text { Group } 3)\end{array}$} & \multirow{4}{*}{5 min. $^{a}$} & 1 & 19 & 0.05 & \multirow{4}{*}{0.0375} & \multirow{8}{*}{$\begin{array}{c}\text { Mann-Whitney } U=16,00 \\
P=0.029\end{array}$} \\
\hline & & 1 & 19 & 0.05 & & \\
\hline & & 0 & 20 & 0.00 & & \\
\hline & & 1 & 19 & 0.05 & & \\
\hline & \multirow{4}{*}{$10 \mathrm{~min}}$. & 16 & 4 & 0.80 & \multirow{4}{*}{0.7625} & \\
\hline & & 16 & 4 & 0.80 & & \\
\hline & & 15 & 5 & 0.75 & & \\
\hline & & 14 & 6 & 0.70 & & \\
\hline \multirow{8}{*}{$\begin{array}{c}-80^{\circ} \mathrm{C} \\
(\text { Group } 4)\end{array}$} & \multirow{4}{*}{30 sec. $^{b}$} & 2 & 18 & 0.10 & \multirow{4}{*}{0.1125} & \multirow{8}{*}{$\begin{array}{c}\text { Mann-Whitney } U=10,50 \\
P=0.486\end{array}$} \\
\hline & & 2 & 18 & 0.10 & & \\
\hline & & 3 & 17 & 0.15 & & \\
\hline & & 2 & 18 & 0.10 & & \\
\hline & \multirow{4}{*}{$1 \mathrm{~min}}$. & 3 & 17 & 0.15 & \multirow{4}{*}{0.1375} & \\
\hline & & 2 & 18 & 0.10 & & \\
\hline & & 4 & 16 & 0.20 & & \\
\hline & & 2 & 18 & 0.10 & & \\
\hline
\end{tabular}

* Since normality assumptions are not satisfied for some of the groups, non-parametric tests are used.

(a) indicates the best duration, there is a statistically significant difference between methods.

(b) indicates easy-to-use duration, there is no statistically significant difference between methods.

Table 5. The comparison of death rate in honey bees for methods with anesthetic level 4 and 5 .

\begin{tabular}{cccc}
\hline Anesthetic Level & Chilling Method (Temperature/Duration) & Average & \multicolumn{2}{c}{ Comparison* $^{*}$} \\
\hline \multirow{2}{*}{4} & $+4^{\circ} \mathrm{C} / 20 \mathrm{~min}$. & 0.075 & Mann-Whitney \\
& $-80^{\circ} \mathrm{C} / 30 \mathrm{sec}$. & 0.1125 & $\mathrm{U}=13.00 \quad \mathrm{P}=0.200$ \\
\hline & $+4^{\circ} \mathrm{C} / 30 \mathrm{~min} .^{\mathrm{b}}$ & 0.1625 & \\
& $-20^{\circ} \mathrm{C} / 5 \mathrm{~min} .^{\mathrm{a}}$ & 0.0375 & One Way ANOVA \\
& $-20^{\circ} \mathrm{C} / 10 \mathrm{~min} .^{\mathrm{c}}$ & 0.7625 & $\mathrm{~F}=231.56 \quad \mathrm{P}<0.001$ \\
& $-80^{\circ} \mathrm{C} / 1 \mathrm{~min} .{ }^{\mathrm{b}}$ & 0.1375 & \\
\hline
\end{tabular}

*Since normality assumptions are not met in Level 4 groups, non-parametric tests are used.

(a), (b) and (c) indicates homogenous subsets of methods obtained via Duncan's homogenous subsets. 


\section{Discussion and Conclusion}

Anesthesia is used commonly in apiculture for the immobilization of honey bees. There is a very small number of studies on the anesthesia of bees. The most commonly used anesthesia method in honey bees is the inhalation of $\mathrm{CO}_{2}$ gas, which rapidly induces loss of consciousness $(7,8)$. There are several studies about the side effects of $\mathrm{CO}_{2}$ treatment on honey bees. The effects of anesthesia in the bees are proportional to the exposure time to $\mathrm{CO}_{2}$ and its concentration $(1,7,19,29)$. Anesthesia results in a lethal effect with increasing exposure to $\mathrm{CO}_{2}$ in honey bees (10). It was reported in several studies that honey bees exposed to $\mathrm{CO}_{2}$ had shortened life-span, reduced pollen-collecting tendency, a decrease in food foraging, and changes in their reproductive state $(18,22$, $23,27)$. There is evidence that anesthesia performed by $\mathrm{CO}_{2}$ before instrumental insemination of queen bees prevents them from performing mating flights in insemination (30). Chilling anesthesia can be an alternative anesthetic method to $\mathrm{CO}_{2}$ anesthesia due to the problems resulting from physical and behavioral changes caused by $\mathrm{CO}_{2}$ anesthesia on honey bees, failure to supply $\mathrm{CO}_{2}$ to laboratories, and the equipment required for $\mathrm{CO}_{2}$ anesthesia. Chilling has the advantage of easy application in honey bees. Hypothermia has been used to slow the metabolic rate in some species of animals, and to facilitate manipulation and noninvasive techniques. However, hypothermia is not recommended for surgical and other invasive procedures. Some invertebrates (e.g. camel spiders) may not be able to tolerate chilling very well and may eventually die (6). There is no study on literature to determine the optimal chilling method in honey bees according to laboratory facilities and the desired depth of anesthesia. Therefore, in this study, the ideal chilling method has been determined by evaluating a high survival rate and depth of anesthesia in different temperatures and durations.

The cooling method showed a significant effect on the exposure time required for immobilization. The duration and dose of cold exposure can affect phenotypic responses, including worker longevity, and learning and foraging behavior in honey bees $(8,11)$. Furthermore, a study has reported that cold exposure caused death and older worker bees were more sensitive to cold than young worker bees (24). Ebadi et al. (8) recommended a method in which the bee was exposed to $-20^{\circ} \mathrm{C}$ for 3 minutes to immobilize mature individuals up to one minute of immobilization. Moreover, it was reported in a review paper that keeping some invertebrates in the refrigerator for 30 minutes at $4^{\circ} \mathrm{C}$ was sufficient for anesthesia induced by chilling (6). In this study, Method 2 (at $-20^{\circ} \mathrm{C}$ for 3 min.), which had with the least mortality rate in Group 2, was similar to the method reported by Edabi and colleagues (8). However, the anesthesia generated by
Method 2 had Level 3 strength, and it may not provide sufficient anesthesia depth to perform any application on the bees. With this method, only a light anesthesia was established from which the workers woke quickly, in less than 1 minute. In this study, no statistically significant difference was determined in the mortality rate between 20 and 30 minutes in Group $1(\mathrm{P}=0.057)$, and between 30 seconds and 1 minute in Group $3(\mathrm{P}=0.486)$. There was a statistically significant difference between 5 and 10 minutes in Group $2(\mathrm{P}=0.029)$ (Table 4). These results suggest that 5-minute application time gives better results than 10-minute application time in this group. It was determined in our study that the chilling protocol with the most ideal anesthesia was 5 minutes at $-20^{\circ} \mathrm{C}$ in terms of high survival rate $(\mathrm{P}<0.001)$ and depth of anesthesia (Level 5) on the honey bees.

The anesthetic method used on honey bees should prove to be safe (in terms of bee recovery) and facilitate the handling and manipulation of the bees (5). There were differences between immobilization times among the methods in our study. These differences may be due to the fact that applications were performed at different temperatures and for different periods. The mortality rate was directly proportional to the duration of chilling applied to the groups. A negative correlation was found between temperature and survival rates, while a positive correlation was determined between duration and mortality rate. For safe anesthesia, the minimum cold exposure time should be preferred that is required for the anesthetization of bees in any experiment. In conclusion, fast and safe anesthesia was performed on honey bees by keeping them in a freezer at a temperature of $-20^{\circ} \mathrm{C}$ for 5 minutes in this study. This chilling method provided lower mortality rate and high depth of anesthesia. Furthermore, any of the methods at Level 4 and 5 may be preferred for an easy and convenient application on honey bees in any study.

\section{Financial Support}

This research received no grant from any funding agency/sector.

\section{Ethical Statement}

This study does not present any ethical concerns.

\section{Conflict of Interest}

The authors declared that there is no conflict of interest.

\section{References}

1. Austin GH (1955): Effect of carbon dioxide anaesthesia on bee behaviour and expectation of life. Bee World, 36, 4547. 
2. Becher MA, Scharpenberg H, Moritz RFA (2009): Pupal developmental temperature and behavioral specialization of honeybee workers (Apismellifera L.). J Comp Physiol A, 195, 673-679.

3. Bogdanov S, Jurendic T, Sieber R, et al (2008): Honey for nutrition and health: a review. J Am Coll Nutr, 27, 677-689.

4. Bühler A, Lanzrein B, Wille H (1983): Influence of temperature and carbon dioxide concentration on juvenile hormone titre and dependent parameters of adult worker honey bees (Apismellifera L.). J Insect Physiol. 29, 885-893.

5. Cooper JE (2001): Invertebrate anesthesia. Vet Clin North Am Exot Anim Pract, 4, 57-67.

6. Cooper JE (2011): Anesthesia, analgesia, and euthanasia of invertebrates. ILAR J, 52, 196-204.

7. Czekońska K (2009): The effect of different concentrations of carbon dioxide $\left(\mathrm{CO}_{2}\right)$ in a mixture with air or nitrogen upon the survival of the honey bee (Apismellifera). $\mathrm{J}$ Apic Res, 48, 67-71.

8. Ebadi R, Gary NE, Lorenzen K (1980): Effects of carbon dioxide and low temperature narcosis on honey bees, Apismellifera. Environ Entomol, 9, 144-150.

9. Engels W, Ramamurty RS (1976): Initiation of oogenesis in allatectomised virgin honey bee queens by carbon dioxide treatment. J Insect Physiol, 22, 1427-1432.

10. Eskov EK, Eskova MD, Spasik SE (2013): Changes in body mass and life span of honeybee Apismellifera L. under effect of narcotization with carbon dioxide. $\mathrm{J}$ Evol Biochem Physiol, 49, 627-629.

11. Frost EH, Shutler D, Hillier NK (2011): Effects of cold immobilization and recovery period on honeybee learning, memory, and responsiveness to sucrose. J Insect Physiol, 57, 1385-1390.

12. Groening J, Venini D, Srinivasan MV (2018): Effects of cold anaesthesia on the defensive behaviour of honeybees. Insect Soc, 65, 359-366.

13. Harris JW, Woodring J (1995): Elevated brain dopamine levels associated with ovary development in queenless worker honey bees (Apismellifera L.). Comp Biochem Physiol C Pharmacol Toxicol Endocrinol, 111, 271-279.

14. Harris JW, Woodring J, Harbo JR (1996): Effects of carbon dioxide on levels of biogenic amines in the brains of queenless worker and virgin queen honey bees (Apis mellifera). J Apic Res, 35, 69-78.

15. Human H, Brodschneider R, Dietemann V, et al (2013): Miscellaneous standard methods for Apis mellifera research. J Apic Res, 52, 1-53.

16. Jones CJ, Helliwell P, Beekman M, et al (2005): The effects of rearing temperature on developmental stability and learning and memory in the honeybee, Apis mellifera. $\mathrm{J}$ Comp Physiol A,191, 1121-1129.

17. Klein AM, Vaissiere BE, Cane JH, et al (2007): Importance of pollinators in changing landscapes for world crops. Proc R Soc B, 274, 303-313.

18. Koywiwattrakul $P$, Thompson GJ, Sitthipraneed $S$, et al (2005): Effects of carbon dioxide narcosis on ovary activation and gene expression in worker honeybees, Apis mellifera. J Insect Sci, 5, 1-10.

19. Madras-Majewska B, Kaminski Z, Balcerak M, et al (2013): Effect of different oxygen and nitrogen ratios in bees awakened from carbon dioxide anesthesia on their behavior and survival after this exertion. Med Weter, 69, 760-762

20. Neumann P, Carreck NL (2010): Honey bee colony losses. J Apic Res, 49, 1-6.

21. Nicolas G, Sillans D (1989): Immediate and latent effects of carbon dioxide on insects. Annu Rev Entomol, 34, 97116.

22. Olszewski K, Borsuk G, Paleolog, et al (2012): Influence of carbon dioxide anaesthesia on the length of worker life and food foraging in cage tests. Med Weter, 68, 615-617

23. Ribbands CR (1950): Changes in the behaviour of honeybees following their recovery from anaesthesia. J Exp Biol, 27, 302-310.

24. Robinson GE, Visscher PK (1984): Effect of low temperature narcosis on honey bee (Hymenoptera: Apidae) foraging behaviour. Fla Entomol, 67, 568-570.

25. Southwick EE (1985): Allometric relations, metabolism and heart conductance in clusters of honey bees at cool temperatures. J Comp Physiol B, 156, 143-149.

26. Stabentheiner A, Kovac H, Brodschneider R (2010): Honeybee colony thermoregulation-regulatory mechanisms and contribution of individuals in dependence on age, location and thermal stress. PLoS One, 5, e8967.

27. Tustain RCR, Faulke J (1979): Effect of carbon dioxide anaesthesia on the longevity of honey bees in the laboratory. New Zeal J Exp Agr, 7, 327-329.

28. Tutun H, Koç N, Kart A (2018): Plant essential oils used against some bee diseases. Turkish JAF Sci Tech, 6, 34-45.

29. Wilde J, Sobiechowski K (2002): The effect of carbon dioxide treatment on matinf of virgin honeybee queens. Pol J Natur Sci, 12, 73-85.

30. Woyke J, Fliszkiewicz C, Jasiñski Z (2001): Prevention of natural mating of instrumentally inseminated queen honeybees by proper method of instrumental insemination. J Apic Sci, 45, 101-114. 